\title{
A DESCRIPTIVE STUDY ON WORK-LIFE BALANCE OF TURKISH EMPLOYEES IN VARIOUS SECTORS DURING COVID-19 PANDEMIC
}

\author{
COVİD-19 PANDEMİSI SIRASINDA ÇEŞİTLİ SEKTÖRLERDEKİ TÜRK \\ ÇALIŞANLARIN İŞ-YAŞAM DENGESİ ÜZERİNE BETIMLEYİCI BİR \\ ARAŞTIRMA
}

Nihan YAVUZ AKSAKAL ${ }^{*}$

\begin{abstract}
With the Covid-19 pandemic, which is a very new period, many organizations had to quickly adapt to working from home or working remotely. Especially for the health and safety of their employees, there are many organizations that have switched to working from home, and still some organizations are continuing it. As a research article, this work examines the work-life balance of employees and statistical differences in terms of a variety of characteristics during the Covid-19 pandemic. A survey was conducted with 165 employees, and the SPSS 24 Package program was used for analysis. In the study, the work-life balance of employees during the pandemic differed statistically significantly by gender, age, marital status, lifestyle, sector, and position. In terms of having children, education level and receiving phone or e-mail working hours, there are no statistically significant differences in work-life balance.
\end{abstract}

Keywords: Work-life balance, covid-19, pandemic, coronavirus.

JEL Classification: M1, M12, M19

Öz

Çok yeni bir süreç olan ve içinde bulunduğumuz Covid-19 pandemi sürecinde birçok organizasyonun hızlı şekilde evden çalışma/uzaktan çalışma sistemine adapte olması gerekmiştir. Özellikle çalışanların sağlıklarını ve güvenliklerini sağlayabilmek adına birçok organizasyon evden çalışma sistemine geçmiş ve hatta bazı organizasyonlar bu süreci halen devam ettirmektedir. Bu makale, bir araştırma makalesi olup Covid-19 pandemisi sürecinde çalışanların iş-yaşam dengelerini ve çeşitli özellikler açısından istatistiksel farklılıkları ortaya koymayı amaçlamaktadır. Araştırma, toplamda 165 çalışan ile anket kullanılarak yapılmıştır. Verilerin analizinde SPSS 24 paket programı kullanılmıştır. Araştırma sonuçlarına göre,

* $\quad$ Res. Assist. İstanbul Ticaret Üniversitesi, İşletme Fakültesi, nyavuz@ticaret.edu.tr, ORCID: 0000-0002-1603-2520.

To cite this article: Yavuz Aksakal, N. (2021). A Descriptive Study on Work-Life Balance of Turkish Employees in Various Sectors During Covid-19 Pandemic. Journal of Research in Business, 6(2), 493-509. 
çalı̧̧anların pandemi sürecindeki iş-yaşam dengesi cinsiyete, yaşa, medeni duruma, yaşam tarzına, çalıştıkları sektöre ve pozisyona göre istatistiksel olarak anlamlı şekilde farklılaşmaktadır. İş yaşam dengesi çocuk sahibi olma, eğitim seviyesi ve mesai dışında telefon/mail alma durumuna göre istatistiksel olarak anlamlı bir farklılık görülmediği saptanmıştır.

Anahtar Kelimeler: İş-yaşam dengesi, Covid-19, pandemi, koronavirüs.

JEL Sinıflaması: M1, M12, M19

\section{Introduction}

The new type of Coronavirus, first discovered in late 2019, has spread worldwide since its emergence, leading to the Covid-19 to date. The Covid-19 virus has greatly affected social life in all countries where it has spread since the day it emerged. The pandemic can also be considered as a dynamic psychological and social period that forces all individuals and all institutions to act with new strategies. With this new order that harms the life balance, it is very important to take into account the psychological health of the employees as well as the physical health and to create a healthier working life with the supportive interventions of the organizations.

The World Health Organization regards the ongoing coronavirus (Covid-19) as the defining global health crisis of our time, but describes it as a pandemic (WHO, 2020; UNDP). The coronavirus pandemic both affects people's physical health and causes a decrease in their life satisfaction (IGHI, 2020; Rajkumar, 2020). Due to the pandemic, most employees (globally) had to work at home, and one of the issues affected as a result is work-life balance (Kumar and Mokashi, 2020). For this reason, it is important to examine the effect of the pandemic on work-life balance of employees.

There are many aspects of life. It's quite difficult to establish and keep a balance between these aspects. Two of these aspects are work and family. While it is difficult to strike this balance under normal conditions, even when the work and family life spheres are in separate locations, the increase in home-based work during the pandemic has made it even more difficult to reconcile. Because the pandemic has brought about major changes changes especially in business life. One of them is the sudden and rapid expansion of home/remote working in many sectors. Home/remote working has become more prevalent during the pandemic as it reduces the physical coexistence of employees. This situation, along with the pandemic, carries the period we call the "new normal" into our business life. Although working at home/distant working saves time in the new normal working life, on the other hand, using the home as both a private life space and a business area often causes these two areas to be mixed with each other due to issues such as distraction and role requirements. For this reason and because it is a current issue, it is very important to properly analyze the work-life balance in order to increase both the quality of work and the quality of life in the current pandemic period. This study aims to measure the work-life balance of employees in various sectors during the pandemic.

This descriptive study aims to identify various outcomes related to work-life balance regarding the work-life balance of employees during the pandemic period. Data were analyzed using SPSS. This study examines differences in work-life balance based on variables such as marital status, gender, children, age, sector and position of employees during/post pandemic. The average daily working hours before and after the pandemic are compared and statistical differences are revealed. 


\section{Work-Life Balance and Related Studies in the Pandemic Period}

Work-life balance is identifed as pleasure, functionality and satisfaction at home and at work, with minimal role conflict (Greenhaus et al., 2003: 512). Work-life balance is also explained as the degree to which an individual can balance the temporal, emotional and behavioral demands of both paid work and family responsibility at the same time (Sarker et al., 2012: 144). According to a different definition, work-life balance is identifed as a person's involvement in work roles and individual roles and being equally satisfied (Johari et al., 2018: 110). In work - life balance, the need for individuals to undertake and fulfill the multiple roles they have in their lives is at the forefront. The timesharing ratios between the two different areas of work and family and the balancing of the roles that individuals take on are very important. It has been suggested that the lack of balance between work and non-work activities is associated with decreased psychological and physical well-being (Hughes and Bozionelos, 2007). Considering the person-centered approach as life roles change and increase over time, it is argued that work-life balance may change depending on career and life stages as well as differences in values and goals (Bhumika, 2020).

It is argued that in a balanced life, "to have satisfying experiences in all areas of life" and for this, personal resources such as energy, time and commitment should be well distributed among areas (Kalliath and Brough, 2008: 325). The lives of all people in work life are divided between time at work and time outside work. Time management, which is one of the limited resources, helps to create a balanced work-life (Kirchmeyer, 2000).

Work-life balance is also about job flexibility, which determines the capacity of employees to define where, when and how they work. It includes elements such as the work program, workplace environment, reward and incentive structure, workloads and policies related to leaves (Uddin, 2021). Work-life balance is also about how to create a healthy and supportive work environment that improves employee performance (Wolor et al., 2020). In addition, work-life balance may vary depending on individual factors such as age, gender, marital status, education. It can also vary depending on organizational factors such as participation in management, responsibility, role ambiguity, role conflict, excessive workload; and working environment (Yavuz and Doğan, 2019).

There are various approaches in the literature regarding work-life balance and the relationship between work/life areas. The compensation theory is that individuals spend more time in one area than the other, and in case of not reaching satisfaction in one area, they aim to reach total satisfaction by turning to the other area more. The situation in which a positive or negative factor experienced in one area is reflected in the other area in the same way is explained as the spill over theory. The view that work and living spaces are unrelated, separate and unaffected by each other is the segmentation theory. While it is the contribution theory that different areas increase the general satisfaction of the individual, conflict due to various roles and responsibilities is called the conflict theory. The theory in which one of the fields is used as a tool to contribute to the other is called the instrumentality theory (Yavuz and Doğan, 2019). A different theory is the work/family boundary theory put forward by Clark (2000). It's argued that the primary connection between work 
and non-work areas is not "emotional" but "human". In theory there are four fields: home space business space, borders, border crossers (people), border protectors. It is suggested that according to the way people manage borders, the work-life balance will change, borders will be determined, and people's relations with that area and people in that area can be determined (Clark, 2000). In the work-family interaction model decoded by Zedeck (1987), the relationship between the family organization and the employing organization is examined. There are three factors in this interaction: work, family and workplace(employing organization). In theory, it is suggested that family and employing organizations are both organizations, two areas where people work. In addition to, the relationship between these two areas may result in spill over or compensate in the individual. This situation supports the spill over and compensation theories. Guest's (2002) work-life balance model includes the primary issues that need to be clarified in the work-life balance analysis. The nature of work-life balance is defined as subjective or objective. Objective indicators include working hours, activities at home, family roles. Subjective indicators point to situations of balance and imbalance, and if the areas are balanced, no conflict is foreseen. It is stated that these indicators are related to each other. In the model, work-life balance outcomes are work and life satisfaction, mental health, performance at work and home, impact on others at work and home.

While all familiar patterns in the business environment are being reorganized with the pandemic, one of the issues affected by this situation is work-life balance. Even before the pandemic, the balance between the domains could falter and overlap from time to time, but this situation is more common in home/remote working. For this reason, studies on work-life balance during the pandemic point to important findings.

Adisa et al. (2021), examined the work-life balance of British women working during the Covid-19 pandemic. It was confirmed that work-life balance depends on the resources expended such as time, attention and energy to fulfill the demands and role expectations from family and work. They emphasize that reducing one area and allocating more resources to another area may cause workfamily conflict. In the Covid-19 pandemic, the combination of working at home and work and family roles creates conflict between roles and disrupts the balance. It has been concluded that while it creates functional difficulties as a result of long working hours and the burden of housework, it causes tensions within the role. In addition, it is claimed that during the pandemic, women spend more time at home with their children, and supervising them (Adisa et al., 2021).

In the study conducted by Bhumika (2020), the conflict between work and family while working from home during the pandemic emerges as one of the sources of emotional exhaustion among employees. However, in the gender variable, a difference was seen in the involvement of personal life, and it was concluded that women were stronger than men.

A different study about the work-life balance of women working in the pandemic also argues that it increases flexibility for employees. As employees in the pandemic are allowed to work at home, work lower hours, or work according to alternative schedules. It is noted that factors such as colleagues, managers, corporate support, and the workplace environment affect the work-life balance during the 
pandemic. It highlights work flexibility and home/telework as the main drivers of work-life balance in the pandemic (Uddin, 2021).

In a study examining the effect of work-life balance on employee performance during the pandemic, it is argued that work-life balance has a positive and significant effect on employee performance and work motivation. It is thought that control over work and family roles will increase employee performance (Wolor et al., 2020).

In the research by Gigauri (2020), which focuses on the impact of Covid-19 on human resources management, as well as digitalization and work-life balance, it is determined that while employees are at work, they only focus on work, while working at home has distracting factors such as child care and housework. As a result, it is concluded that employees are forced to perform their duties in the evening, home-work-rest areas are intertwined, and that there is a lot of psychological pressure and tension when there are other members of the family who work distant.

In the study examining work-life balance and work stress when working at home during the pandemic in Indonesia, it is revealed that working at home has a significant and negative effect on work-life balance both directly and indirectly. It is argued that since employees are accustomed to fixed working hours in the workplace, they have difficulty in dividing their time between their work and private lives (Irawanto et al., 2021).

In a study conducted by Putranti et al. (2020), it was found that men and women have different patterns in discriminating time. It is concluded that women can divide their time more between work and social life in later ages. It is concluded that men are more able to devote time to work at home at the age of 20-30 years, and women are more able to devote time to work at home in the age 4160 years. It is argued that housework, having children and child care can be seen as the reason why women can make this distinction at a later age than men.

In the study of Del Boca et al. (2020) in which they compared work, housework and child care of women before and after the pandemic, it was concluded that the pandemic further increased the workload of women arising from both their professions and domestic responsibilities. In this period, it seems that men are starting to spend more time caring for children.

Considering the studies on work-life balance during the pandemic, it is seen that it is mostly focused on female employees. As a common aspect of the studies, it is concluded that female employees have more difficulties in establishing work-life balance due to their home and work roles. However, it is foreseen that if employees can achieve work-life balance, they will be able to show higher performance and flexibility and organizational/managerial support will provide positive results in terms of work-life balance.

\section{Purpose of the Study and Hypotheses}

Although remote and flexible working is practiced by many organizations, the Covid-19 pandemic has made this option mandatory for a while. Many employees from different sectors continued 
to work almost entirely within the digital life in this period. This makes it necessary to reveal the work-life balance status of employees with different characteristics from different sectors. This study involved 165 workers from different sectors and in different positions who worked at home or remotely during the pandemic. It's purposed to reveal the differences in work-life balance according to the work-life balance of the employees and the demographic features of the employees during the Covid-19. It is thought that re-measuring the work-life balance during the Covid-19 pandemic, that is a new era, will contribute to the literature by presenting a different perspective.

The study seeks answers to the following questions:

- Are employees able to establish a work-life balance during the Covid-19 pandemic? Have the employees been able to establish a work-life balance in this period?

- Is there any difference in the work-life balance of employees during the Covid-19 pandemic according to gender, age, sector, position, marital status, education level, having a child and lifestyle?

- Have there been any changes (increase or decrease) in the working hours of the employees during the Covid-19 pandemic?

In this context, the following hypotheses have been developed for the research.

$\boldsymbol{H}_{1}$ : Employees' work-life balance differs statistically and significantly during the Covid-19 pandemic according to gender.

$\boldsymbol{H}_{2}$ : Employees' work-life balance differs statistically and significantly during the Covid-19 pandemic according to age.

$\boldsymbol{H}_{3}$ : Employees' work-life balance differs statistically and significantly during the Covid-19 pandemic according to marital status.

$\boldsymbol{H}_{4}$ : Employees' work-life balance differs statistically and significantly during the Covid-19 pandemic according to having a child/children.

$\boldsymbol{H}_{5}$ : Employees' work-life balance differs statistically and significantly during the Covid-19 pandemic according to lifestyle.

$\boldsymbol{H}_{6}$ : Employees' work-life balance differs statistically and significantly during the Covid-19 pandemic according to education level.

$\boldsymbol{H}_{7}$ : Employees' work-life balance differs statistically and significantly during the Covid-19 pandemic according to sector.

$\boldsymbol{H}_{8}$ : Employees' work-life balance differs statistically and significantly during the Covid-19 pandemic according to position/title.

$\boldsymbol{H}_{9}$ : There is a significant difference in the average daily working hours of the employees before the covid-19 and during the covid-19 pandemic period. 


\section{Methodology and Analysis}

\subsection{Participants and Procedures}

In the study where employees working at home during the pandemic period were included in the population, random sampling was used where any participant who is accessible to the researcher could be included in the sample. Moreover, the study used random sampling method which is one of the nonrandom sampling methods considering constraints such as cost, time constraints and population size. An online questionnaire form prepared through GoogleForms was used to collect data in the research. In the first part of the survey, the demographic information of the participants, in the second part, the statements about work-life balance and in the third part, the statements about working hours are included.

\subsection{Measures}

Work-life balance scale used in this study consists of 10 expressions. Work-life balance scale developed by Netemeyer, Boles and McMurrian (1996) was used in this study. Each dimension on a two-dimensional scale, including the impact of work on family life and the impact of family on business life, contains 5 expressions. Expressions are measured by using Likert-type scale (1: strongly disagree, 5: strongly agree). During the study, the participants were asked to consider their work processes during the pandemic when answering the questions regarding work-life balance.

SPSS 24 statistical package program was used to analyze the data. The following tests were used according to the purpose of the research: frequency analysis for demographic findings, independent two-sample t-test for gender, marital status, and childbearing, one-way ANOVA test for educational status, lifestyle, industry, position and age variables. In addition, an independent two-sample t-test was used for the situation of receiving phone/e-mail at non-working hours during the pandemic. Frequency analysis and ANOVA test were used for the average daily working hours before and during the pandemic. In addition, the Cronbach alpha reliability test findings for the work-life balance scale were examined.

\subsection{Data and Variables}

In Table 1, the demographic features of the participants and their sector and position information are given. 94 women (\%57), 71 men participated in the study. Of the participants, 66 (\%40) were between the ages of $18-30,65$ (\%39.4) were between the ages of $31-43,16(\% 9.7)$ were between the ages of 44-56, and 18 (\%10.9) is more than 56 years old. Of the participants, 92 (\%55.8) were married and 73 (\%44.2) were single. 38 (\%23) of the participants have children; 127 (\%77) did not have children. 50 (\%30.3) of the participants live with their families, 92 (\%55.8) with their partner/wife/husband and 23 (\%13.9) of the participants live alone. 73 (\%44.2) of the participants are undergraduate and 92 (\%55.8) graduates. There are no primary or high school graduates. The sectors in which the participants work are as follows: banking (\%5.5), information technology (\%10.9), education (\%36.4), chemistry/cosmetics (\%9.7), tourism (\%13.9), insurance (\%8.5), finance (\%8.5) and textile (\%6.7). 62 (\%37.6) of the participants were academicians, 36 (\%21.8) managers/executives, 12 (\%7.3) assistant managers, 39 (\%23.6) specialists, 16 of them (\%9.7) are assistant specialists. 
Table 1: Descriptive statistics

\begin{tabular}{|c|c|c|c|c|c|}
\hline Gender & Frequency $(\mathrm{N})$ & Percentage & Age & Frequency $(\mathrm{N})$ & Percentage \\
\hline Female & 94 & 57.0 & 18-30 years old & 66 & 40.0 \\
\hline Male & 71 & 43.0 & $31-43$ years old & 65 & 39.4 \\
\hline \multirow[t]{3}{*}{ Total } & 165 & 100.0 & 44-56 years old & 16 & 9.7 \\
\hline & & & more than 56 & 18 & 10.9 \\
\hline & & & Total & 165 & 100.0 \\
\hline Marital Status & Frequency $(\mathrm{N})$ & Percentage & Having Children & Frequency $(\mathrm{N})$ & Percentage \\
\hline Married & 92 & 55.8 & Yes & 38 & 23 \\
\hline Single & 73 & 44.2 & No & 127 & 77 \\
\hline Total & 165 & 100.0 & Total & 165 & 100.0 \\
\hline Lifestyle & Frequency $(\mathrm{N})$ & Percentage & Education Level & Frequency (N) & Percentage \\
\hline With family & 50 & 30.3 & Primary Education & - & - \\
\hline $\begin{array}{l}\text { With partner (wife/ } \\
\text { husband) }\end{array}$ & 92 & 55.8 & High School & - & - \\
\hline Alone & 23 & 13.9 & Undergraduate & 73 & 44.2 \\
\hline With housemate & - & - & Graduate & 92 & 55.8 \\
\hline Total & 165 & 100.0 & Total & 165 & 100.0 \\
\hline Sector & Frequency $(\mathrm{N})$ & Percentage & Position/Title & Frequency (N) & Percentage \\
\hline Banking & 9 & 5.5 & Academician & 62 & 37.6 \\
\hline Information/technology & 18 & 10.9 & Manager/Executive & 36 & 21.8 \\
\hline Education & 60 & 36.4 & Assistant Manager & 12 & 7.3 \\
\hline Chemistry/Cosmetics & 16 & 9.7 & Specialist & 39 & 23.6 \\
\hline Tourism & 23 & 13.9 & Assistant Specialist & 16 & 9.7 \\
\hline Insurance & 14 & 8.5 & Total & 165 & 100.0 \\
\hline Finance & 14 & 8.5 & & & \\
\hline Textile & 11 & 6.7 & & & \\
\hline Total & 165 & 100.0 & & & \\
\hline
\end{tabular}

KMO and Bartlett tests, the KMO value was calculated as 0.842 for the work-life balance scale. It can be said that this value is excellent (Sipahi et al., 2008, 80). The significance level of the Barlett Test of Sphericity was found (p:0.000<0.01). The Cronbach alpha value of the work-life balance scale was found to be 0.923 and this value indicates that reliability is provided. In the common variance values (communalities) for the items, it is seen that all values are higher than 0.638. As Field (2009: 645) stated, expressions with a factor load of less than 0.50 should be excluded. So, the expression was not extracted because all values were above 0.60. As shown in Table 2, since two of the eigenvalues in the total explained variance table are greater than 1 (4.511 and 3.782), a two-factor structure can be studied. As a result of the factor analysis, two factors were obtained and these factors explain $82.921 \%$ of the total variance. These results indicate the validity of the scale's two-factor structure consisting of 10 items. 
Table 2: Factor analysis results of work-life balance scale

\begin{tabular}{|c|c|c|}
\hline Items & $\begin{array}{l}\text { Work-Family Life Balance } \\
\text { Sub-Dimension }\end{array}$ & $\begin{array}{l}\text { Family-Work Balance } \\
\text { Sub-Dimension }\end{array}$ \\
\hline $\begin{array}{l}\text { WLB1 (The demands of my work interfere with my home and } \\
\text { family life.) }\end{array}$ & 0.930 & \\
\hline $\begin{array}{l}\text { WLB2 (The amount of time my job takes up makes it difficult } \\
\text { to fulfill family responsibilities.) }\end{array}$ & 0.929 & \\
\hline $\begin{array}{l}\text { WLB3 (Things I want to do at home do not get done because } \\
\text { of the demands my job puts on me.) }\end{array}$ & 0.911 & \\
\hline $\begin{array}{l}\text { WLB4 (My job produces strain that makes it difficult to fulfill } \\
\text { family duties.) }\end{array}$ & 0.884 & \\
\hline $\begin{array}{l}\text { WLB5 (Due to work-related duties, I have to make changes to } \\
\text { my plans for family activities.) }\end{array}$ & 0.875 & \\
\hline $\begin{array}{l}\text { WLB6 (The demands of my family or spouse/partner interfere } \\
\text { with work-related activities.) }\end{array}$ & & 0.947 \\
\hline $\begin{array}{l}\text { WLB7 (I have to put off doing things at work because of } \\
\text { demands on my time at home.) }\end{array}$ & & 0.947 \\
\hline $\begin{array}{l}\text { WLB8 (Things I want to do at work don't get done because of } \\
\text { the demands of my family or spouse/partner.) }\end{array}$ & & 0.865 \\
\hline $\begin{array}{l}\text { WLB9 (My home life interferes with my responsibilities at } \\
\text { work such as getting to work on time, accomplishing daily } \\
\text { tasks, and working } \\
\text { overtime.) }\end{array}$ & & 0.820 \\
\hline $\begin{array}{l}\text { WLB10 (Family-related strain interferes with my ability to } \\
\text { perform job-related duties.) }\end{array}$ & & 0.615 \\
\hline Eigenvalues & 4.511 & 3.782 \\
\hline Variance Explained & $\% 45.106$ & $\% 37.815$ \\
\hline Total Explained Variance & \multicolumn{2}{|c|}{ \%82.921 } \\
\hline
\end{tabular}

As shown in Table 3, the means and standard deviations of the items in the scale.

Table 3: Statistics on items

\begin{tabular}{lccc}
\hline & Item Statistics & \\
\hline & Mean & Std. Deviation & N \\
WLB1 $^{*}$ & 2.9273 & 1.35504 & 165 \\
WLB2 $^{*}$ & 2.9152 & 1.40732 & 165 \\
WLB3 $^{*}$ & 2.7697 & 1.52069 & 165 \\
WLB4$^{*}$ & 2.8242 & 1.41831 & 165 \\
WLB5 $^{*}$ & 2.7030 & 1.51103 & 165 \\
WLB6 $^{* *}$ & 3.6424 & 1.18400 & 165 \\
WLB3 $^{* *}$ & 3.9152 & 1.32244 & 165 \\
WLB8 $^{* *}$ & 4.0121 & 1.22468 & 165 \\
WLB9 $^{* *}$ & 3.6848 & 1.31967 & 165 \\
WLB10 $^{* *}$ & 4.0909 & 1.10882 & 165 \\
\hline
\end{tabular}

${ }^{*}$ (work-family life balance sub-dimension)

** (family-work balance sub-dimension) 


\section{Findings}

In the research, for the work life balance of the employees in the pandemic; gender, age, education level, lifestyle, having a child, the sector they work in, the position they work in, and the variables of receiving phone/email outside of working hours were examined. For this purpose, difference analyzes were performed as shown in Table 4. Work-life balance of employees in the pandemic, it differs significantly according to gender, age, marital status, lifestyle, sector and position. According to independent sample test result, the work-life balance of women is higher than that of men, and work-life balance of singles is higher than married people. According to the Levene's test result, the work-life balance of the participants differs significantly according to gender $\left(\mathrm{t}_{(163)}=2.373 ; \mathrm{p}<0.05\right)$. According to the Levene's test result, the work-life balance of the participants differs significantly according to marital status $\left(\mathrm{t}_{(163)}=-3.428 ; \mathrm{p}<0.05\right)$.

Table 4: Difference tests (T-tests) for work-life balance

\begin{tabular}{|c|c|c|c|c|}
\hline & & Work- & nce & \\
\hline Variables & Mean & Std. Deviation & $t$ & Sig. (p) \\
\hline Gender & & & 2.373 & 0.019 \\
\hline Female & 3.5191 & 0.85651 & & \\
\hline Male & 3.1225 & 1.19537 & & \\
\hline Marital Status & & & -3.428 & 0.001 \\
\hline Married & 3.1109 & 1.06611 & & \\
\hline Single & 3.6479 & 0.90862 & & \\
\hline Having Children & & & -0.733 & 0.467 \\
\hline Yes & 3.2263 & 1.22401 & & \\
\hline No & 3.3850 & 0.96954 & & \\
\hline Non-Working Hours Phone/e-Mail & & & -0.311 & 0.757 \\
\hline Yes & 3.3315 & 0.91006 & & \\
\hline No & 3.4053 & 1.37643 & & \\
\hline
\end{tabular}

As shown in Table 5, according to the ANOVA test result, the work-life balance of the participants differs significantly according to age $\left.\mathrm{F}_{(3,161)}=4.264, \mathrm{p}<0.05\right)$. The group with the highest worklife balance is between the ages of 18-30, while the group with the lowest work-life balance is in the between the ages of 44-56. According to the ANOVA test result, the work-life balance of the participants differs significantly according to lifestyle $\left.\mathrm{F}_{(2,162)}=8.543, \mathrm{p}<0.05\right)$. Those who live with their families have the highest work-life balance, while those who live with their spouses have the lowest. According to the ANOVA test result, the work-life balance of the participants differs significantly according to sector $\left.\mathrm{F}_{(7,157)}=6.391, \mathrm{p}<0.05\right)$. While the information technology sector has the highest work-life balance, the textile sector has the lowest. According to the ANOVA test result, the work-life balance of the participants differs significantly according to position/title $\mathrm{F}_{(4,160)}=2.814$, $\mathrm{p}<0.05)$. Managers/Executives have the highest work-life balance, while assistant specialists have the lowest work-life balance. Work-life balance does not show a significant difference according to the group of having children, education level and receiving phone/e-mail at non-working hours. 
Table 5: Difference tests (ANOVA) for work-life balance

\begin{tabular}{|c|c|c|c|c|}
\hline \multicolumn{5}{|c|}{ Work-Life Balance } \\
\hline Variables & Mean & Std. Deviation & $\mathrm{F}$ & Sig. (p) \\
\hline Age & & & 4.264 & 0.006 \\
\hline $18-30$ years old & 3.6061 & 1.03298 & & \\
\hline 31-43 years old & 3.1492 & 1.02593 & & \\
\hline $44-56$ years old & 2.8063 & 0.75319 & & \\
\hline More than 56 & 3.6056 & 0.98606 & & \\
\hline Lifestyle & & & 8.543 & 0.000 \\
\hline With family & 3.8240 & 0.88791 & & \\
\hline With partner (wife/husband) & 3.1109 & 1.06611 & & \\
\hline Alone & 3.2652 & 0.84992 & & \\
\hline With housemate & - & & & \\
\hline Education Level & & & 2.298 & 0.132 \\
\hline Primary Education & - & & & \\
\hline High School & - & & & \\
\hline Undergraduate & 3.2123 & 1.11255 & & \\
\hline Graduate & 3.4565 & 0.95541 & & \\
\hline Sector & & & 6.391 & 0.000 \\
\hline Banking & 3.1444 & 1.42926 & & \\
\hline Information/Technology & 4.2889 & 1.07915 & & \\
\hline Education & 3.4533 & 0.94555 & & \\
\hline Chemistry/Cosmetics & 2.8250 & 0.79289 & & \\
\hline Tourism & 2.9391 & 1.07227 & & \\
\hline Insurance & 4.0214 & 0.48545 & & \\
\hline Finance & 2.9429 & 0.42556 & & \\
\hline Textile & 2.6818 & 0.82803 & & \\
\hline Position/Title & & & 2.814 & 0.027 \\
\hline Academician & 3.4032 & 0.96001 & & \\
\hline Manager/Executive & 3.6389 & 1.03600 & & \\
\hline Assistant Manager & 2.8250 & 0.25628 & & \\
\hline Specialist & 3.3821 & 1.14934 & & \\
\hline Assistant Specialist & 2.7938 & 1.10843 & & \\
\hline
\end{tabular}

As stated in article 63 of the 4857 Turkish Labor Law [4857 Turkish Labor Law, 2003, article 63], "In general terms, working time is 45 hours a week at most. Unless there isn't any other agreement, , this period is applied in workplaces by dividing it equally into the working days of the week." And, as stated in article 68 of the same law, "The rest breaks are not counted as working time." (4857 Labor Law). Considering the articles specified in the Labor Law, the weekly working hours of a full-time employee are generally around 45 hours in Turkey. When working at home before the pandemic and especially during the pandemic was compared, there were changes in the working times in general according to the answers given by the participants. Before the pandemic, there was an increase in the working hours of those who worked less than 7.5 hours, those who worked between 10.5-12 hours and those who worked more than 12 hoursIn particular, the rate of working for more than 12 hours increased from 3\% before the pandemic to $10.9 \%$ 
during the pandemic. When this situation is evaluated in general, it can be thought that these employees shorten their "life" times and add to their "work" periods during the periods when working at home. However, there was a decrease in the rate of employees working between 7.5 and 9 hours. This situation can be interpreted as a result of the stagnation of the sectors for those who work between 7.5 and 9 hours.

Table 6: Daily working time of participants

\begin{tabular}{lcccc}
\hline \multicolumn{5}{c}{ Daily Average Working Time } \\
\hline & \multicolumn{2}{c}{ Before Pandemic } & \multicolumn{2}{c}{ During the Pandemic } \\
\hline Frequency & Percent & Frequency & Percent \\
\hline less than 7,5 hours & 21 & 12.7 & 36 & 21.8 \\
between 7,5-9 hours & 85 & 51.5 & 52 & 31.5 \\
between 9-10,5 hours & 38 & 23.0 & 38 & 23.0 \\
between 10,5-12 hours & 16 & 9.7 & 21 & 12.7 \\
more than 12 hours & 5 & 3.0 & 18 & 10.9 \\
Total & 165 & 100.0 & 165 & 100.0 \\
\hline
\end{tabular}

When Table 7 is examined, work-life balance differs significantly according to the working hours of the participants before the pandemic. While the group with the highest work-life balance before the pandemic was less than 7.5 hours, the group with the lowest work-life balance was those who worked more than 12 hours. At this point, it can be said that the balance of work-life balance level is minimum. Given the pandemic period/post-pandemic period, work-life balance also differs significantly according to the working hours of the participants. The group which has higher work-life balance level was employees between 7.5-9 hours, while the group with the least was employees between 9-10.5 hours.

Table 7: ANOVA Test for work-life balance of participants in terms of working hours before and during the pandemic

\begin{tabular}{|c|c|c|c|c|}
\hline \multicolumn{5}{|c|}{ Work-Life Balance } \\
\hline & Mean & Std. Deviation & F & Sig. \\
\hline $\begin{array}{l}\text { Average daily working time before the } \\
\text { pandemic }\end{array}$ & & & 9.044 & 0.000 \\
\hline less than 7.5 hours & 4.4190 & 0.87041 & & \\
\hline between 7.5-9 hours & 3.1647 & 0.96532 & & \\
\hline between 9-10.5 hours & 3.1763 & 1.04918 & & \\
\hline between $10.5-12$ hours & 3.5813 & 0.74137 & & \\
\hline more than 12 hours & 2.5400 & 0.05477 & & \\
\hline & Mean & Std. Deviation & $\mathrm{F}$ & Sig. \\
\hline $\begin{array}{l}\text { Average daily working time during/ } \\
\text { post-pandemic }\end{array}$ & & & 3.652 & 0.007 \\
\hline less than 7.5 hours & 3.4417 & 1.27758 & & \\
\hline between 7.5-9 hours & 3.7058 & 1.12728 & & \\
\hline between $9-10.5$ hours & 2.9289 & 0.84722 & & \\
\hline between $10.5-12$ hours & 3.1619 & 0.68810 & & \\
\hline more than 12 hours & 3.2333 & 0.34641 & & \\
\hline
\end{tabular}




\section{Conclusion and Discussion}

With the Covid-19 pandemic, meetings in physical locations have been replaced by online meetings and work at the workplace has been replaced by remote work / work from home. This situation leads to the addition of the business domain to the life domain, and sometimes this situation leads to imbalances. This study examines the work-life balance of employees during the pandemic period and whether the work-life balance differs in terms of various variables. In addition, the study aims to reveal the average daily working hours before and during the pandemic.

To briefly summarize the findings of this study: work-life balance of the employees during the pandemic period differs statistically significantly according to gender, age, marital status, lifestyle, sector and position. Work-life balance of women is higher than that of men, and the work-life balance of singles is higher than that of married people. According to the results of the study conducted by Bhumika (2020), it was also found that women's work-life balance is stronger than men's. From this point of view, the results of this study seem to be in line with the Bhumika's (2020) study. Work-life balance is highest at the age of 18-30 years and lowest at the age of 44-56 years. While the work-life balance was highest among those living with their family, it was the lowest among those living with their partner/wife/husband. People living with their spouses have a lower worklife balance due to distractions such as children and housework (Gigauri, 2020). While the work-life balance is the highest in the information technology sector, the lowest is seen in the textile sector. In the study, in which the sectors with the highest work-life balance during the pandemic period were investigated, the sectors with the highest work-life balance scores were the pharmaceutical, information technologies and finance sectors (Marketing Türkiye, 2020). From this point of view, it can be said that the results of the study are in parallel with literature. However, it is thought that a statistically significant evaluation based on comparison cannot be made, especially since the number of participants from certain sectors is very low. While the work-life balance level of the managers/ executives was the highest, work-life balance of the assistant specialists was the lowest. It can be thought that managers and executives can balance their work and life areas with their experience, while young employees such as assistant specialists have difficulty in work-life balance due to their new participation in business life. According to all these results; $\mathrm{H}_{1}, \mathrm{H}_{2}, \mathrm{H}_{3}, \mathrm{H}_{5}, \mathrm{H}_{7}, \mathrm{H}_{8}$ hypothesis was supported.

One objective indicator of work-life balance is working hours. Providing the free time needed for employees outside of work by reducing their weekly working hours with flexible work schedules is seen as important policies in establishing the balance of work-life (Akın et al., 2017). It is seen that as the working hours increase, the work-life balance decreases. It can be said that employees devote time to the work area by sacrificing their living spaces and work-life balance decreases. According to the results of two studies examining the working hours of those working from home due to the Covid-19 pandemic, 38\% of the respondents stated that they work longer hours, and in the other study, $27 \%$ of those who work from home also work in their free time to fulfill their work demands (ILO, 2020: 5). 
It is claimed that working remotely increases the work intensity, creates a work-home conflict and causes negative effects on the stress levels of the employees (ILO, 2020). At the same time, working without considering the work-life balance may seem positive for organizations at first glance, but it can lead to a decrease in productivity in the long term. In Covid-19 pandemic, suggestions that can be implemented by organizations, practitioners and managers in order to create an effective and productive working environment and results are given below:

- Considering marital status and gender, it's important to create flexible work schedules suitable for the needs of the employees (Yadav et al., 2021; ILO, 2020),

- During the Covid-19 pandemic, it is important to share responsibilities, according to result of this study especially since married individuals have a lower work-life balance compared to singles.

- Considering the work-life balance of those working for more than 12 hours and less than 7.5 hours during the pandemic, it is very important to manage the time.

- It's important to communicate openly and effectively between employees and employers (Yadav et al., 2021; ILO, 2020),

- As a result of the study, considering the high increase in the number of employees working more than 12 hours during the pandemic, it is important to support employees to take breaks when necessary,

- During Covid-19 pandemic, since the employees are not physically present at the workplace it's important to creating the opportunity to socialize with colleagues in the virtual environment,

- According to the results of the study, due to the fact that the work-life balance of the employees during the covid-19 process is lower than that of the managers/executives it's important to support them in asking for help from the manager, teammates or the organization when necessary, provide organizational support (Irawanto et al., 2021).

It is very important to balancing work-life, especially in a difficult period such as a pandemic, is to draw the boundaries of the field correctly, to make room for short breaks during working hours, to be in contact with people and to be able to manage time. The results of this study are limited by the data collection tools, time-cost constraint and the sample reached. It should also be taken into account that limitations arising from the current research model and variables, and that confounding variables may have an impact on the findings. In order to generalize the research results, it is recommended to create a larger sample group and to use different data sources together. There is a necessary to conduct a research to put forth which variables affect the work-life balance during the Covid-19 pandemic. In future studies, it is thought that it is important to examine work-life balance on a global scale, with more variables that are thought to affect work-life balance and to examine their effects on work-life balance. It is thought that it will contribute to the literature studies conducted during the pandemic, business life, managers and employees in order to show the work-life balance of the employees in this period. 


\section{Author Contribution}

The entire study was done by Phd candidate-Research Assistant Nihan YAVUZ AKSAKAL.

\section{Conflict of Interest}

The author declares no potential conflicts of interest.

\section{Financial Support}

The author received no financial support for the research, authorship, and/or publication of this article.

\section{References}

4857 Labor Law, Retrieved from https://www.mevzuat.gov.tr/MevzuatMetin/1.5.4857.pdf , Received on 03.06.2021.

Adisa, T.A., Aiyenitaju, O. \& Adekoya, O.D. (2021). The work-family balance of British working women during the COVID-19 pandemic. Journal of Work-Applied Management. Retrieved from https://doi. org/10.1108/JWAM-07-2020-0036.

Akın, A., Ulukök, E. \& Arar, T. (2017). İş-yaşam dengesi: Türkiye’de yapılan çalışmalara yönelik teorik bir inceleme. Journal of Economics and Administrative Sciences, 19(1), 113-124.

Bhumika. (2020). Challenges for work-life balance during covid-19 induced nationwide lockdown: exploring gender difference in emotional exhaustion in the Indian setting. Gender in Management, 35(7/8), 705718. https://doi.org/10.1108/GM-06-2020-0163.

Clark, S. C. (2000). Work/Family border theory: A new theory of work/family balance. Human Relations, 53(6), 747-770.

Del Boca, D., Pggero, N., Profeta, P. \& Rossi, M.C. (2020). Women's work, housework, and childcare before and during covid-19. IZA Institute of Labor Economics, No. 13409.

Field, A. (2009). Discovering Statistics Using SPSS. London, Sage Publications, 3rd edition.

Gigauri, I. (2020). Effects of Covid-19 on human resource management from the perspective of digitalization and work-life-balance. International Journal of Innovative Technologies in Economy, 4(31), 1-10 https:// doi.org/10.31435/rsglobal_ijite/30092020/7148.

Greenhaus, J.H., Collins, K.M. \& Shaw, J.D. (2003). The relation between work-family balance and, quality of life. Journal of Vocational Behavior, 63(3), 510-531.

Guest, D. (2002). Perspectives on the study of work-life balance. Social Science Information, 41(2), 255-279.

Hughes, J. \& Bozionelos, N. (2007). Work-life balance as source of job dissatisfaction and withdrawal attitudes: An exploratory study on the views of male workers. Personnel Review, 36(1), 145-154.

ILO (2020). Covid-19 ortamında ve sonrasında uzaktan çalışma, Retrieved from https://www.ilo.org/wcmsp5/ groups/public/--europe/_-ro-geneva/--ilo-ankara/documents/publication/wcms_759299.pdf , Received on 01.07.2021.

ILO (2020). Teleworking during the COVID-19 pandemic and beyond, Retrieved from

https://www.ilo.org/wcmsp5/groups/public/_-ed_protect/-protrav/travail/documents/instructionalmaterial/ wcms_751232.pdf, Received on 27.10.2021. 
Irawanto, D.W., Novianti, K.R. \& Roz, K. (2021). Work from home: measuring satisfaction between work-life balance and work stress during the Covid-19 pandemic in Indonesia. Economies, 9(96), 1-13 https://doi. org/10.3390/economies9030096.

Johari, J., Yean Tan, F. \& Zulkarnain, Z.I.T. (2018). Autonomy, workload, work-life balance and job performance among teachers. International Journal of Educational Management, 32(1), 107-120.

Kalliath, T. \& Brough, P. (2008). Work-life balance: A review of the meaning of the balance construct. Journal of Management \& Organization, 14(3), 323-327.

Kirchmeyer, C. (2000). Work-life initiatives: greed or benevolence regarding workers' time C.L. Cooper, D.M. Rousseau (Eds.), Trends in organisational behaviour, 7, John Wiley \& Sons, Chichester, 79-93.

Kumar, R. \& Mokashi, U.M. (2020). COVID-19 and Work-life balance: What about supervisor support and employee proactiveness?. Annals of Contemporary Developments in Management \& HR, 2(4), 1-9.

Marketing Türkiye, (2020). Retrieved form https://www.marketingturkiye.com.tr/haberler/is-yasamdengesinde-sampiyon-ilac-sektoru/, Received on 01.07.2021.

Netemeyer, R.G., Boles, J. \& McMurrian, R. (1996). Development and validation of work, family conflict and family work conflict scales. Journal of Applied Psychology, 81(4), 400-410.

Putranti, H.R.D., Suparmi, S. \& Susilo, A. (2020). Work life balance (WLB) complexity and performance of employees during Covid-19 pandemic. Journal of Business Management and Accounting, 4(1), 56-68.

Rajkumar, R.P. (2020). Covid-19 and mental health: A review of the existing literature. Asian Journal of Psychiatry, 52. https://doi.org/10.1016/j.ajp.2020.102066

IGHI, (2020). Institute of Global Health Innovation, Global insights on life satisfaction - Covid-19 behaviour tracker, Imperial College London, Technical Report July 2020.

Sarker, S., Xiao, X., Sarker, S. \& Ahuja, M. (2012). Managing employees' use of mobile technologies to minimize work / life balance, impacts. MIS Quarterly Executive, 11(4), 143-157.

Sipahi, B. Yurtkoru, E. S. \& Çinko, M. (2008). Sosyal Bilimlerde SPSS'le Veri Analizi, İstanbul: Beta Basım Yayım Dağıtım.

Uddin, M. (2021). Addressing work-life balance challenges of working women during covid-19 in Bangladesh. International Social Science Journal, 71(239-240), 7-20. https://doi.org/10.1111/issj.12267

UNDP, Covid-19 Pandemic, Retrieved from https://www.tr.undp.org/content/turkey/en/home/coronavirus. html, Received on 06.06.2021.

WHO. (2020). Coronavirus disease 2019 (COVID-19) Situation Report-51, (11.02.2020 report), Retrieved from https://www.who.int/docs/default-source/coronaviruse/situation-reports/20200311-sitrep-51covid-19.pdf?sfvrsn=1ba62e57_10, Received on 06.06.2021.

Wolor, C.W., Solikhah, S., Fidhyallah, N.F. \& Lestari, D.P. (2020). Effectiveness of e-training, e-leadership, and work life balance on employee performance during Covid-19. Journal of Asian Finance, Economics and Business, 7(10), 443-450.

Yadav, MJ., Jadhav -Tilekar, S. (2021). A study of work-life balance of women employees during work from home in the period of COVID-19. I nternational Journal of Future Generation Communication and Networking, 14(1), 2063-2066.

Yavuz, N. \& Doğan, A. (2019). İş stresinin iş-yaşam dengesi üzerindeki etkisinin esnek çalışma bağlamında test edilmesi. İstanbul Ticaret Üniversitesi Sosyal Bilimler Dergisi, 18(35), 41-62.

Zedeck, S. (1987). Work, family, and organizations: An untapped research triangle, IRLE Institute Research on Labor and Employment - IRLE Working Paper No: 10-87. 


\section{Resume}

Nihan YAVUZ AKSAKAL (Res. Assist.) is a Research Assistant of Business Administration at Faculty of Business, İstanbul Ticaret University since 2016. She has a bachelor's degree in business administration from Istanbul University and a master's degree in human resources management from the same university. She has continued Ph.D. in Human Resource Management in Business from Istanbul University. Her research interests focus on the areas of work-life balance, career management, intellectual capital, personality, artificial intelligence. In addition she has private sector experience on human resources in different sectors. 